\title{
Perubahan Temperature Humidity Index (THI) di Pulau Jawa sejak 1981 hingga 2019
}

\author{
Qurrata A'yun Kartika ${ }^{1,2 *}$, Rahmat Hidayat $^{1}$ dan Rista Hernandi Virgianto ${ }^{3}$
}

${ }^{1}$ Institut Pertanian Bogor, Dramaga Bogor, Jawa Barat, Indonesia

${ }^{2}$ Stasiun Klimatologi Tangerang Selatan-BMKG. Jalan Kodam Raya No. 82 Pondok Betung, Pondok Aren, Tangerang Selatan, Jawa Barat, Indonesia

${ }^{3}$ Sekolah Tinggi Meteorologi Klimatologi dan Geofisika, Tangerang Selatan, Jawa Barat, Indonesia

Koresponden Email: ayun.kartikaa@gmail.com

Direvisi: 2021-01-24 Diterima: 2021-03-12

(C)2021 Fakultas Geografi UGM dan Ikatan Geograf Indonesia (IGI)

\begin{abstract}
Abstrak Pulau Jawa mengalami peningkatan jumlah penduduk dari waktu ke waktu. Peningkatan ini berdampak pada tingginya aktivitas antropogenik yang menghasilkan emisi yang diantaranya dapat menyebabkan perubahan suhu udara. Suhu udara sangat berkaitan dengan thermal stress yang mempengaruhi kenyamanan bahkan kesehatan manusia. Thermal stress dapat diukur dengan Temperature Humidity Index (THI) dengan suhu udara rata-rata permukaan dan Relative Humidity (RH) sebagai variabel bebas. Penelitian ini menganalisis sejauh mana perubahan suhu udara permukaan, RH dan THI terhadap waktu. Kemudian daerah dengan perubahan THI yang paling besar akan dianalisis keterkaitannya jumlah penduduk menggunakan korelasi Pearson. Berdasarkan hasil penelitian diketahui terjadi perubahan suhu udara udara permukaan sebesar -0.27 hingga $1.17^{\circ} \mathrm{C}$ diikuti perubahan $\mathrm{RH}$ sebesar $-2.21 \%$ hingga $0.77 \%$ dan terjadi perubahan THI hingga $0,72^{\circ} \mathrm{C}$ sejak 1981 hingga 2019 terutama di pesisir utara bagian barat Pulau Jawa. Selain itu, THI di sekitar DKI Jakarta juga memiliki nilai korelasi simultan yang tinggi dengan jumlah penduduk sebesar 0,81 , korelasi lag 1 tahun sebesar 0,69 , sementara korelasi lag 2 tahun sebesar 0,67. Temuan ini mengindikasikan peningkatan jumlah penduduk berdampak terhadap peningkatan THI pada DKI Jakarta.
\end{abstract}

Kata kunci: Temperature Humidity Index (THI); thermal stress; suhu udara; relative humidity; jumlah penduduk

Abstract Java has experienced an increase in population from time to time. This increase has an impact on high anthropogenic activity which results in emissions, which can cause changes in air temperature. Air temperature is closely related to thermal stress which affects comfort and even human health. Thermal stress can be measured by the Temperature Humidity Index (THI) with the average surface air temperature and Relative Humidity $(\mathrm{RH})$ as the independent variable. This study analyzes the extent of changes in surface air temperature, RH and THI with time. Then the areas with the greatest THI changes will be analyzed for their correlation using the Pearson correlation. Based on the research results, it is found that there has been a change in surface air temperature of -0.27 to $1.17^{\circ} \mathrm{C}$ followed by changes in $\mathrm{RH}$ from $-2.21 \%$ to $0.77 \%$ and there has been a change in THI to $0.72^{\circ} \mathrm{C}$ from 1981 to 2019 , especially on the north coast of the western part of Java. In addition, THI around DKI Jakarta also has a high simultaneous correlation value with a population of 0.81, a 1-year lag correlation of 0.69, while a 2-year lag correlation of 0.67 . These findings indicate an increase in population has an impact on increasing THI in DKI Jakarta.

Keywords: Temperature Humidity Index (THI); thermal stress; air temperature; relative humidity; total population

\section{PENDAHULUAN}

Pulau Jawa merupakan pulau dengan kepadataan penduduk yang paling tinggi di Indonesia, yaitu sebesar 3.625 jiwa per km² pada tahun 2019 (Badan Pusat Statistik, 2020b). Tingginya jumlah penduduk berimplikasi pada tingginya aktivitas manusia terutama pada kota-kota di Pulau Jawa. Ketika aktivitas antropogenik meningkat, emisi yang dihasilkan juga meningkat, sehingga dapat mengakibatkan peningkatan suhu udara permukaan (Wuebbles et al., 2003; Kusminingrum \& Gunawan, 2008). Peningkatan suhu udara akan berkaitan dengan thermal stress yang dapat mengganggu kinerja manusia, seperti penurunan tingkat kewaspadaan dan daya tahan tubuh (Enander, 1989). Thermal stress dibagi menjadi dua, yaitu: heat stress dan cold stress yang menurut Wilson \& Crandall (2011), heat stress dapat meningkatkan aktivitas kinerja jantung yang signifikan, sedangkan pada cold stress tidak signifikan dalam mempengaruhi aktivitas kinerja jantung namun cukup berpengaruh pada kondisi fisik pria terutama yang berusia lanjut daripada wanita. Tapi pada umumnya tingkat kenyamanan pada cold stress tergantung pada gaya hidup dan kebiasaan tiap individu (Smolander, 2002; Wilson \& Crandall, 2011). Thermal stress dapat diukur menggunakan rumus empiris 
Temperature Humidity Index (THI) seperti yang dikemukakan oleh McGregor and Nieuwolt (1998). Selain dalam segi kesehatan, THI dapat digunakan sebagai panduan dalam perencanaan kota, perlindungan konstruksi dan lingkungan (Ige et al., 2017).

Menurut Supari et al. (2017), terjadi peningkatan suhu udara Indonesia dalam tiga dekade terakhir. Khusus di Pulau Jawa, berdasarkan penelitian Susanti et al. (2019) telah terjadi peningkatan rata-rata suhu udara permukaan di Pulau Jawa kurang lebih sebesar $0,3{ }^{\circ} \mathrm{C}$ dari tahun 2000 sampai 2018. Setiawan and Ma'mun (2021) mengemukakan telah terjadi penurunan kecenderungan RH di DAS Ciliwung (Jawa Barat) antara tahun 1985 sampai 2019. Aktivitas manusia ditengarai berdampak pada perubahan suhu (Johannessen et al., 2004), sehingga perubahan suhu akan berpengaruh pada perubahan THI.

Beberapa penelitian terdahulu mengenai THI di Indonesia telah dilakukan meskipun masih terbatas pada kota-kota tertentu dengan data observasi iklim yang sangat terbatas. Tursilowati \& Djundjunan (2007) menemukan kenaikan THI di Surabaya berdasarkan analisis citra satelit pada 1994 dan 2002. Wati \& Fatkhuroyan (2017) juga menemukan kenaikan THI di beberapa tempat di DKI Jakarta selama periode 1985-2012. Marsitha et al. (2019) menganalisis kenaikan THI di kota-kota besar di Pulau Sulawesi antara tahun 1985 sampai 2012 dengan kota Makassar sebagai kota dengan kenaikan THI paling tinggi di Sulawesi. Andani and Sasmito (2018) juga mengemukakan telah terjadi kenaikan THI sejak tahun 2009 sampai 2017 di Semarang. Beberapa penelitian THI di Indonesia dalam skala yang lebih kecil juga dikaitkan dengan tata ruang dan arsitektur (Alfian et al., 2018; Rilo et al., 2018; Ramadhan \& Osly, 2019).

Berdasarkan latar belakang yang telah dikemukakan, maka penelitian ini dilakukan untuk menyempurnakan kajian bagaimana perubahan suhu dan Relative Humidity (RH) yang mempengaruhi perubahan THI di Pulau Jawa serta kaitannya dengan jumlah penduduk pada daerah urban.

\section{METODE PENELITIAN}

Data

Data yang digunakan dalam penelitian ini ialah data suhu udara rata-rata permukaan bulanan reanalisis ERA5 tahun 1981-2019 di Pulau Jawa, data suhu titik embun bulanan reanalisis ERA5 tahun 1981-2019 di Pulau Jawa dan data jumlah penduduk di DKI Jakarta berdasarkan tahun 1981-2019 dari sensus penduduk, Survei Sosial Ekonomi Nasional (Susenas) dan proyeksi jumlah penduduk (Biro Pusat Statistik, 1982, 1983, 1985, 1986, 1987, 1988, 1991, 1992, 1993, 1995, 1996; Badan Pusat Statistik, 1997, 1998, 1999, 2002, 2003, 2004, 2006, 2007, 2008, 2009, 2010, 2011, 2012, 2013, 2014, 2015, 2016, 2017, 2018, 2019, 2020a). Data suhu titik embun digunakan karena pada dataset ERA5 tidak tersedia data $\mathrm{RH}$ sehingga akan digunakan persamaan (1) untuk memperoleh $\mathrm{RH}$ dari suhu titik embun. Pulau Jawa berada pada koordinat $5,8^{\circ}$ hingga $8,8^{\circ}$ LS dan $105^{\circ}$ hingga $115^{\circ}$ BT seperti yang digambarkan pada Gambar 1 .

Data jumlah penduduk menggunakan gabungan data sensus penduduk, Susenas dan Proyeksi data penduduk oleh BPS. Data sensus penduduk dianggap sebagai data aktual, data Susenas dianggap sebagai data semi-aktual dan data proyeksi penduduk dianggap sebagai data pendekatan berdasarkan data historis yang dihimpun oleh BPS, dengan demikian data proyeksi akan tetap memiliki error yang perlu dianalisis besarannya terhadap data aktual. Data Susenas sangat bergantung pada kesadaran penduduk mendaftarkan diri sebagai warga ke Disdukcapil. Kami tidak menemukan catatan yang relevan untuk jumlah penduduk pada tahun 1983 dan 1988.

ERA5 merupakan data asimilasi dari berbagai data observasi (SYNOP, DRIBU, TEMP, PILOT dan AIRCRAFberdasarkan pengamatan atmosfer) dan data satelit, serta dihasilkan dari komputasi dengan performa yang tinggi dari European Centre for Medium-Range Weather Forecasts (ECMWF) dan Copernicus Climate Change Service (C3S) (Hennermann \& Berrisford, 2017; Hersbach et al., 2020) yang menyediakan data dalam skala jam hingga bulanan dengan resolusi spasial $0,1^{0} \times 0,1^{\circ}$ yang dapat didownload melalui laman Copernicus (http://www.copernicus.eu/). Data suhu rata-rata permukaan merupakan data pada ketinggian 2 meter di atas permukaan bumi. Data suhu ini dinyatakan dalam satuan Kelvin, sehingga untuk pengolahan THI, suhu harus dikonversi menjadi derajat Celcius. Data ERA5 digunakan karena mampu merepresentasikan dengan baik pola-pola cuaca yang biasa terjadi di daerah Tropis seperti Indonesia serta mampu mereduksi bias pada curah hujan dibandingkan produk sebelumnya yaitu ERA-Interim (Nogueira, 2020).

Dalam pembobotan THI, data yang dibutuhkan ialah suhu udara permukaan dan RH. Data RH dapat diturunkan dari suhu titik embun dan suhu udara permukaan seperti yang ditunjukkan pada persamaan 1 .

$$
R H \approx 100-5\left(T-T_{d}\right)
$$

(Lawrence, 2005)

dengan $R H$ sebagai kelembaban relatif (\%), $T$ sebagai suhu udara permukaan $\left({ }^{\circ} \mathrm{C}\right)$ dan $T_{d}$ sebagai suhu titik embun $\left({ }^{\circ} \mathrm{C}\right)$.

Periode analisis suhu rata-rata permukaan dan $\mathrm{RH}$ dalam penelitian ini dibagi menjadi 4 periode, antara lain: periode 1 pada tahun 1981-1990, periode 2 pada tahun 1991-2000, periode 3 pada tahun 2001-2010 dan periode 4 pada tahun 2011-2019. Pembagian periode dilakukan per 10 tahun untuk melihat lebih jelas perubahan suhu udara permukaan dan RH yang sangat kecil per tahunnya, serta dianggap dapat merangkum kondisi iklim dalam kurun waktu tersebut (Murphy \& Timbal, 2008).

\section{Thermal Stress berdasarkan THI}

THI sering dikaitkan dengan kenyamanan populasi manusia di luar ruangan dan dinyatakan dalam derajat Celcius (Tseliou et al., 2010; Ige et al., 2017; Njoku \& Daramola, 2019). THI disebut juga discomfort index merupakan indeks yang digunakan untuk mengukur thermal stress secara empiris dan dinotasikan dalam persamaan 2 .

$$
T H I=0.8 T+\left(\frac{R H \times T}{500}\right) \quad \text { (McGregor \& Nieuwolt, 1998) }
$$

\section{Perubahan THI}

Perubahan THI dilakukan untuk melihat bagaimana kecenderungan THI berdasarkan waktu dengan cara memetakan selisih THI periode 4 sebagai periode terkini dengan THI periode 1 sebagai periode awal dengan tujuan melihat perubahan THI 30 tahun setelah periode 


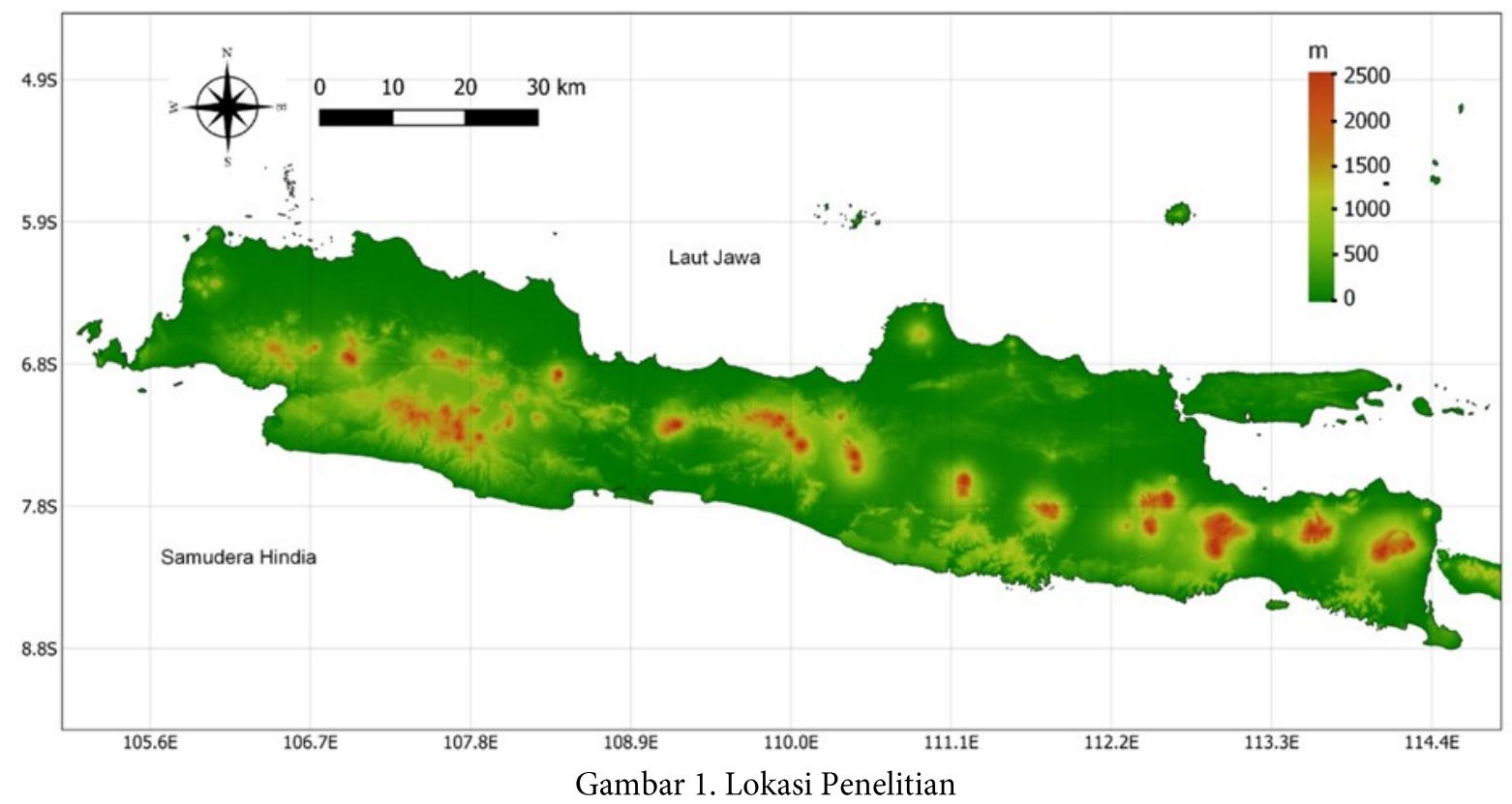

Tabel 1. Klasifikasi THI menurut McGregor \& Nieuwolt

\begin{tabular}{lll}
\hline THI & \multicolumn{1}{c}{ Deskripsi } \\
\hline$<21$ & Dingin (Cold) \\
$21-24$ & Nyaman (Comfortable) \\
$24-26$ & $\begin{array}{l}\text { Cukup Nyaman, sebagian mengalami thermal stress } \\
(\text { Enough comfortable) }\end{array}$ \\
& $>26$ & Tidak Nyaman (Discomfort)
\end{tabular}

awal. Analisis deskriptif dilakukan pada grafik THI dari 4 periode dari beberapa sampel kota di Pulau Jawa, diantaranya DKI Jakarta, Sukabumi, Bandung, Semarang, Malang dan Jember yang mewakili kota di pesisir utara dan selatan serta kota di bagian tengah Pulau Jawa dengan koordinat yang disesuaikan dengan grid pada data. Nilai THI untuk tiap kota dihitung dengan rata-rata nilai THI yang bersesuaian dengan grid kota tersebut.

\section{Korelasi THI dan Jumlah Penduduk}

Setelah menghitung perubahan THI, selanjutnya dicari kota mana yang memiliki selisih THI terbesar antara THI periode 1 dan periode 4 . Pada kota yang memiliki perubahan THI yang besar, data THI bulanan dirata-ratakan menjadi THI tahunan dan kemudian dikorelasikan dengan jumlah penduduk tahunan dengan menggunakan korelasi Pearson. Penelitian ini hanya membandingkan THI dengan jumlah penduduk dan mengasumsikan jumlah penduduk kota yang akan dianalisis tersebar merata pada kota tersebut.

Hasil penelitian ini disajikan dalam bentuk gambar yang diplot dan diekstraksi menggunakan software GrADS. GrADS merupakan software yang dapat digunakan untuk eksekusi data dalam bentuk grid (Berman et al., 2001).

\section{HASIL DAN PEMBAHASAN}

\section{Perubahan Suhu Udara dan RH Permukaan}

Radiasi matahari sebagai sumber energi yang sangat mempengaruhi dinamika suhu di bumi dan secara tidak langsung mempengaruhi musim. Perubahan musim wilayah tropis biasanya dilihat dari presipitasi (Hartmann, 2015). Apabila ditinjau berdasarkan presipitasi, Pulau Jawa yang berada di wilayah tropis memiliki pola hujan monsunal dengan musim hujan terjadi pada Desember-JanuariFebruari dan musim kemarau terjadi pada bulan Juni-JuliAgustus. Penelitian ini menggunakan sampel musim hujan yang diwakili oleh bulan Januari dan musim kemarau oleh bulan Juli.

Suhu udara permukaan rata-rata pada bulan Januari dan bulan Juli di Pulau Jawa direpresentasikan pada Gambar 2. Secara spasial, pada periode 1 hingga periode 4 pada bulan Januari dan Juli suhu udara di Pulau Jawa berkisar antara $<18^{\circ} \mathrm{C}$ sampai $27^{\circ} \mathrm{C}$ dengan kondisi bulan Juli lebih hangat daripada bulan Januari dan wilayah utara Pulau Jawa lebih hangat daripada wilayah selatan Pulau Jawa. Secara temporal, Pada bulan Januari, suhu udara permukaan ratarata yang hangat $\left(>25^{\circ} \mathrm{C}\right)$ tampak menyebar dari periode 1 hingga 4 terutama untuk wilayah pesisir utara Pulau Jawa dan beberapa daerah dengan suhu permukaan rata-rata yang rendah $\left(<19^{\circ} \mathrm{C}\right)$ cenderung menyempit. Demikian pula untuk bulan Juli, dengan kondisi yang lebih hangat daripada bulan Januari yang ditandai dengan mulai adanya suhu udara permukaan rata-rata di atas $27^{\circ} \mathrm{C}$ di utara Pulau Jawa pada periode 2 dan meluas hingga periode 4 . Hal ini menunjukkan terjadi peningkatan suhu udara permukaan di sebagian besar Pulau Jawa selama periode 1981-1990 hingga 20112019 yang sejalan dengan temuan dari penelitian Supari et al. (2017) dan Susanti et al. (2019) yang mengemukakan bahwa telah terjadi kenaikan suhu rata-rata permukaan di Pulau 
Jawa. Kondisi RH sebagai unsur yang merepresentasikan uap air di atmosfer sangat berkaitan dengan curah hujan pada suatu waktu atau musim, dimana ketika musim hujan, $\mathrm{RH}$ di wilayah tropis akan lebih tinggi dibanding musim kemarau. Perubahan RH digambarkan pada bulan Januari dan Juli sebagaimana direpresentasikan pada Gambar 3. Secara spasial, terdapat perbedaan pola $\mathrm{RH}$ pada bulan Januari dan bulan Juli. Pada bulan Januari variasi RH kecil, daerah pesisir Pulau Jawa umumnya memiliki RH yang sedikit lebih rendah dibandingkan dengan daerah dengan lokasi yang lebih jauh dari pantai sedangkan pada bulan Juli variasi RH cenderung besar dan umumnya wilayah utara Pulau Jawa memiliki RH yang lebih rendah (lebih kering) daripada wilayah selatan Pulau Jawa.

Secara temporal, RH bulan Januari dan bulan Juli memiliki pola yang hampir mirip namun tetap dengan variasi yang lebih besar untuk bulan Juli dimana tampak meluasnya daerah $\mathrm{RH}$ yang lebih kecil dari arah utara Pulau Jawa menuju bagian tengah pada periode 1 hingga periode 3 , namun pada periode 4 luasan $\mathrm{RH}$ yang lebih rendah tersebut kembali mengecil namun cenderung masih lebih luas dibandingkan dengan periode 2. Sehingga, umumnya RH cenderung menurun dibandingkan periode awal (periode 1) terutama di Pulau Jawa bagian barat dan timur. Hal ini juga mengkonfirmasi penelitian Setiawan \& Ma'mun (2021) yang menemukan adanya penurunan trend $\mathrm{RH}$ di DAS Ciliwung yang berada di Pulau Jawa bagian barat antara tahun 1985 sampai 2019.
Perubahan THI di Pulau Jawa

Periode THI pada periode 1 digambarkan pada Gambar 4. Berdasarkan Gambar 4 dapat diketahui bahwa Jawa memiliki variasi kenyamanan yang cukup besar sejak periode 1, namun secara keseluruhan umumnya kenyamanan di $\mathrm{Pu}$ lau Jawa berada pada kategori Enough comfortable yang berarti sebagian manusia masih merasa nyaman dan sebagian lagi merasa tidak nyaman. Wilayah selatan Pulau Jawa umumnya memiliki kenyamanan yang lebih baik daripada utara Pulau Jawa. Pada bulan April, Mei, September, Oktober, dan November beberapa wilayah di utara Pulau Jawa berada pada kategori tidak nyaman untuk sebagian besar manusia. Perubahan positif dari THI dapat membuat daerah yang awalnya dalam kategori Cold menjadi Comfortable, Comfortable menjadi Enough comfortable, dan Enough comfortable menjadi Discomfortable dan sebaliknya untuk perubahan negatif. Gambar 4 yang menunjukkan pada periode 1 kondisi umum Pulau Jawa berada pada kategori Enough comfortable, dimana jika terjadi peningkatan THI kondisi ini dapat berubah menjadi kategori Discomfortable.

Perubahan THI pada periode 4 terhadap periode 1 digambarkan pada Gambar 5. Sebagian besar wilayah Pulau Jawa umumnya mengalami perubahan THI positif yang menunjukkan peningkatan THI telah terjadi. Kenaikan suhu udara permukaan selama periode penelitian akan mempengaruhi kenaikan THI karena variabel suhu udara permukaan merupakan variabel utama pada rumus perhitungan THI (McGregor \& Nieuwolt, 1998), walaupun pada beberapa bagian pulau mengalami penurunan RH. Terdapat

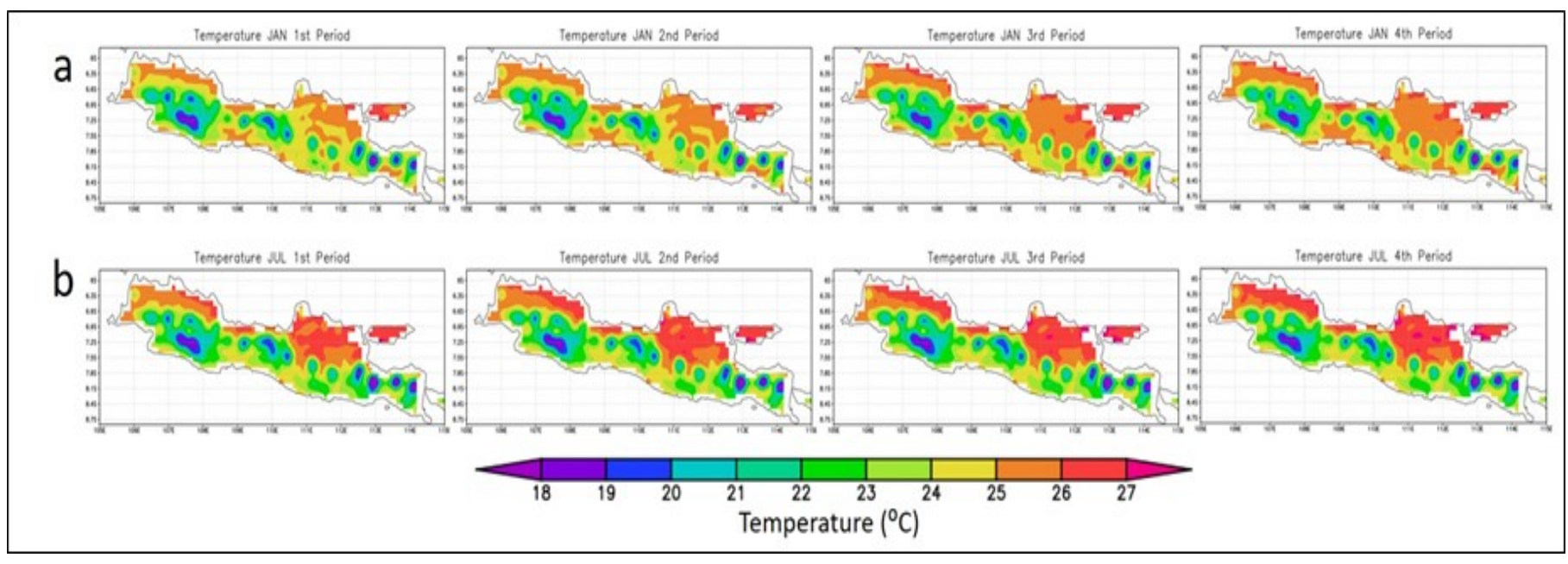

Gambar 2. Suhu udara permukaan pada 4 Periode (a) bulan Januari dan (b) bulan Juli

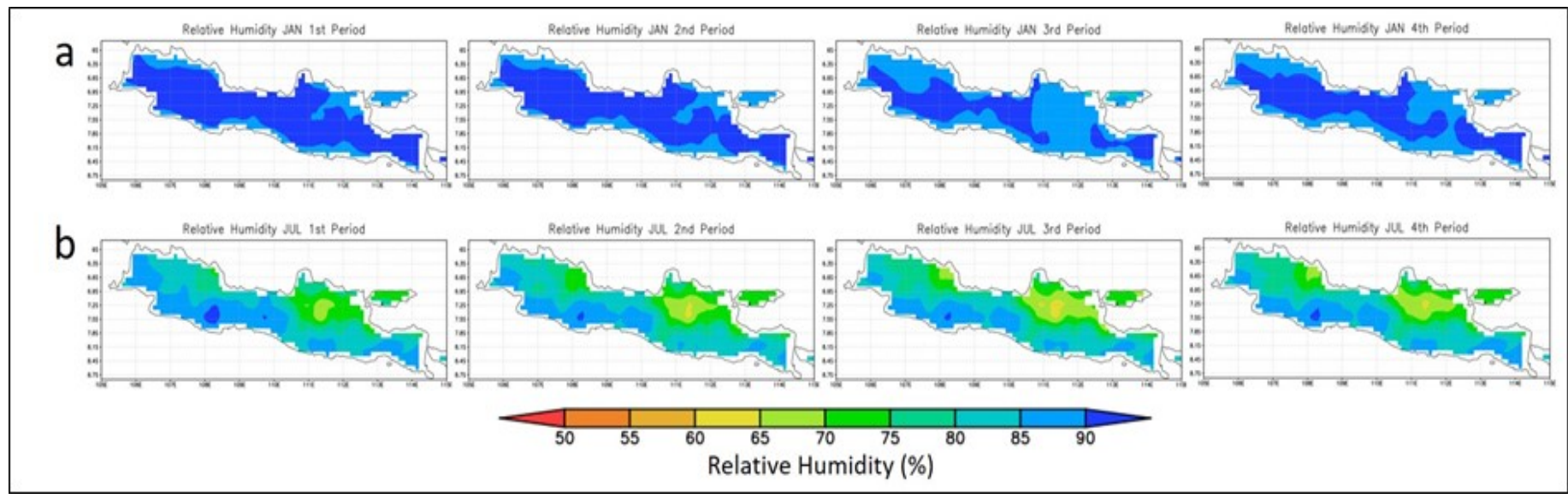

Gambar 3. RH permukaan pada 4 Periode (a) bulan Januari dan (b) bulan Juli 


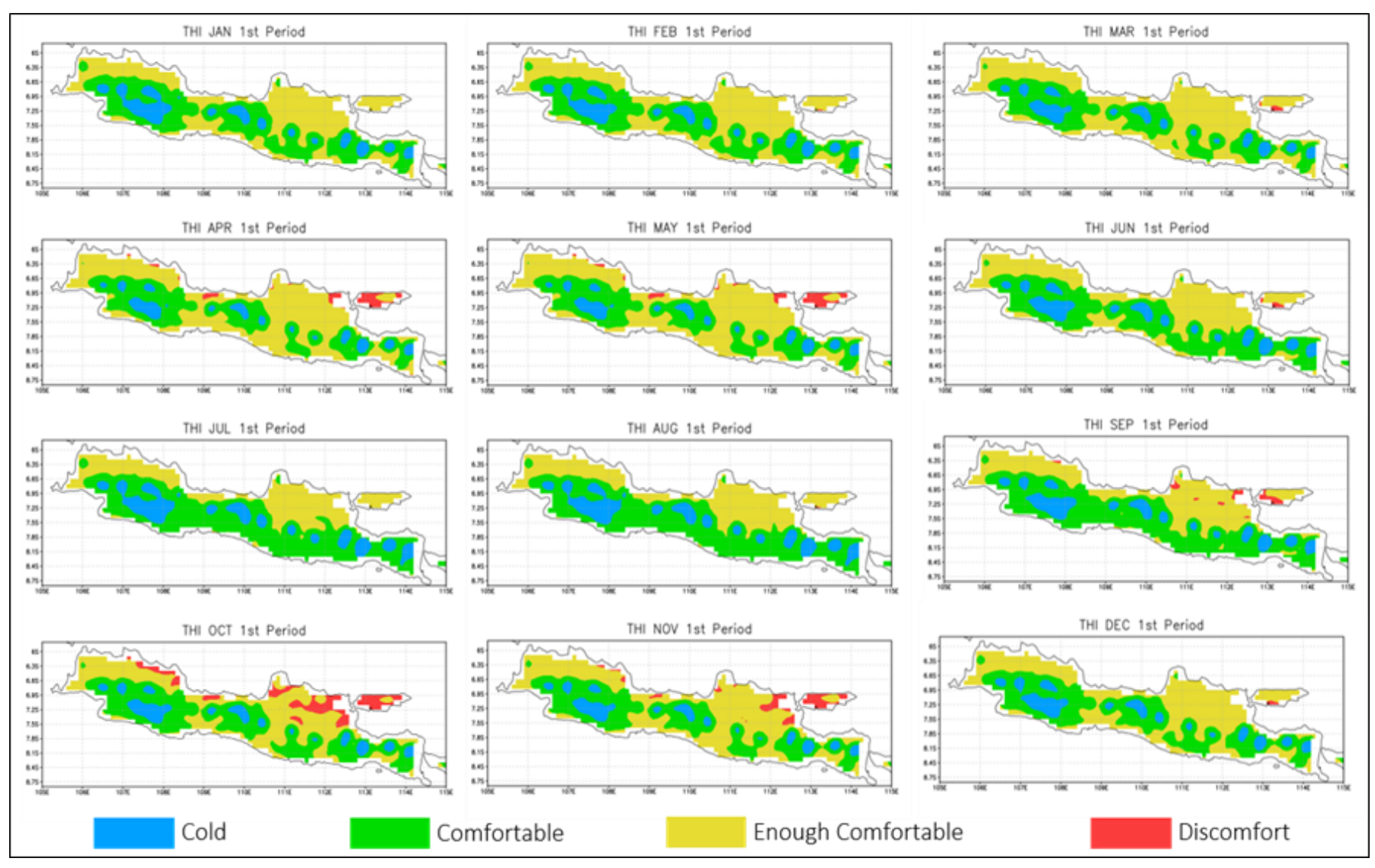

Gambar 4. THI bulanan di Jawa pada periode 1

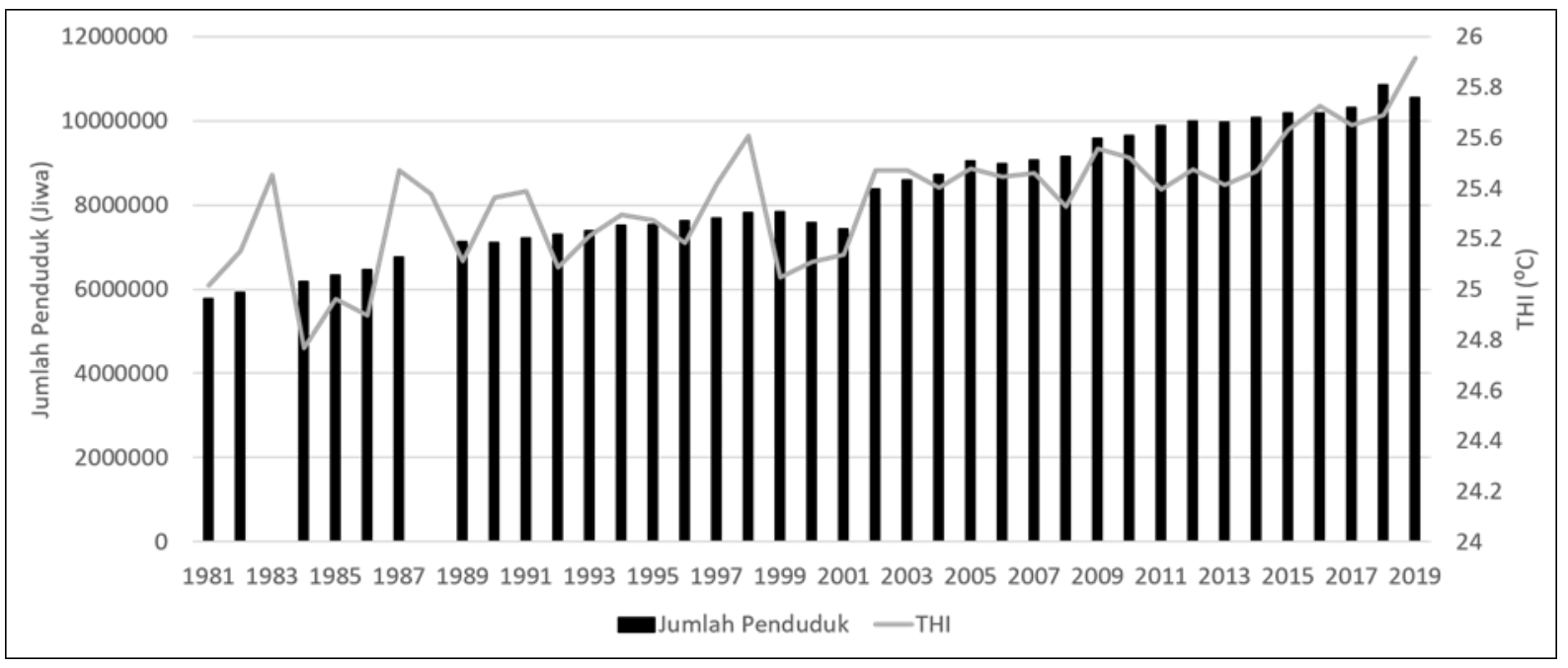

Gambar 7. Grafik jumlah penduduk dan THI di DKI Jakarta

perubahan negatif atau penurunan THI yang terjadi di sebagian selatan dan timur Pulau Jawa pada Agustus. Umumnya utara Pulau Jawa mengalami perubahan yang lebih besar dari selatan Pulau Jawa. Bagian barat Pulau Jawa umumnya mengalami peningkatan THI dengan yang terbesar dapat mencapai $0,72{ }^{\circ} \mathrm{C}$ selama 30 tahun. Namun demikian, nilai maksimum kenaikan THI di Pulau Jawa ini masih lebih rendah dibandingkan dengan nilai maksimum kenaikan THI di Pulau Sulawesi pada penelitian Marsitha et al. (2019) yang dapat mencapai $0,9^{\circ} \mathrm{C}$ selama kurun waktu 30 tahun.

Gambaran perubahan THI di DKI Jakarta, Sukabumi, Bandung, Semarang, Malang dan Jember periode 1 hingga 4 ditunjukkan pada Gambar 6. Pola THI kota-kota di Pulau Jawa umumnya mencapai puncaknya pada bulan Maret dan Oktober, kecuali di Malang dimana dalam 2 dekade terakhir puncak THI terjadi pada bulan November. Sejak periode 1 hingga 4 THI di DKI Jakarta berada dalam kategori enough comfortable, kecuali pada bulan Oktober periode 4 yang sudah dalam kategori discomfort. THI di Semarang pada periode 1 pada bulan Januari, Februari dan Juli berada pada kategori comfort dan enough comfortable untuk bulanbulan berikutnya, pada periode 2 pada bulan Januari berada pada kategori comfort dan bulan-bulan lainnya pada kategori enough comfortable dan pada periode 3 dan 4 dalam kategori enough comfortable.

THI di Malang dan Jember pada periode 1 hingga 4 di tiap bulan berada dalam kategori comfortable, namun dengan variasi bulanan yang cenderung besar. THI terendah secara umum terjadi di Bandung dan THI tertinggi terjadi di DKI Jakarta. Pada bulan Januari hingga Juni dan bulan 


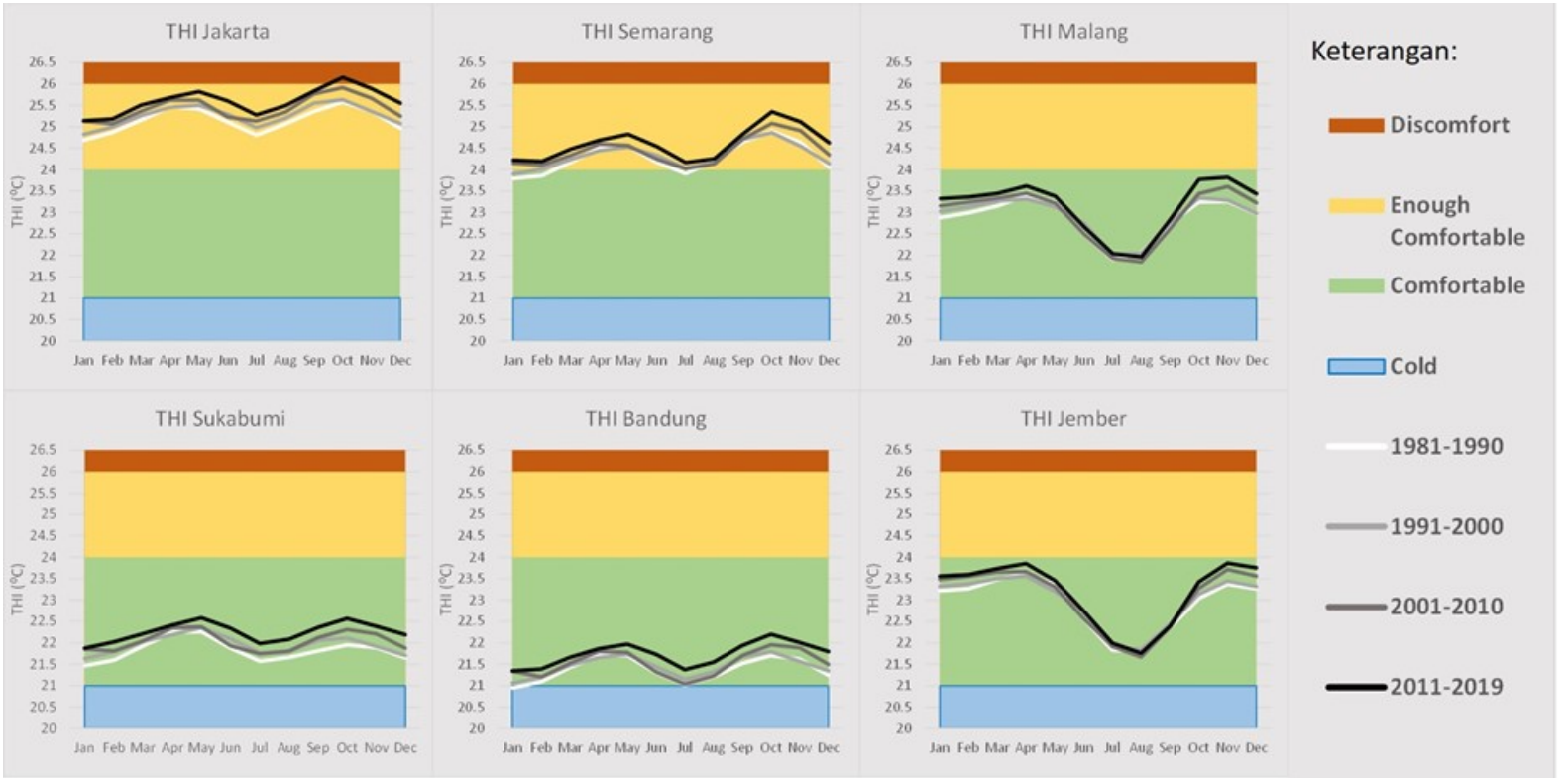

Gambar 6. Perubahan THI di beberapa kota di Pulau Jawa.

November hingga Desember THI di Jember $\sim 0.2^{\circ} \mathrm{C}$ lebih tinggi daripada THI di Malang, namun pada bulan Juli hingga Oktober THI di Jember $\sim 0.2^{\circ} \mathrm{C}$ lebih rendah daripada THI di Malang. Pola THI di Sukabumi dan Bandung mirip dengan $\sim 0.5^{\circ} \mathrm{C}$ lebih besar di Sukabumi daripada di Bandung, berada pada kategori yang sama yaitu comfortable, kecuali pada bulan Januari periode 1 dalam kategori Cold dan grafik cenderung berhimpitan untuk periode 1 hingga 3 kecuali periode 4 yang hampir selalu konstan di atas periode 1 hingga 3. Secara umum, pola THI meningkat seiring periode dan mengurangi kenyamanan terutama untuk kota yang berada di utara Pulau Jawa.

\section{Keterkaitan THI dengan Jumlah Penduduk}

Kenaikan THI tidak lepas dari aktivitas manusia, berdasarkan Gambar 6 diketahui DKI Jakarta merupakan daerah dengan kenaikan THI yang cukup tinggi dan merupakan daerah dengan laju urbanisasi yang relatif tinggi (Harahap, 2013). Oleh karena itu, keterkaitan THI dengan jumlah penduduk dibahas lebih lanjut untuk wilayah DKI Jakarta.

Gambar 7 menggambarkan grafik THI dan jumlah penduduk tahun 1981-2019. Berdasarkan grafik pada Gambar 7, THI di DKI Jakarta memiliki kecenderungan peningkatan dari tahun 1981 hingga 2019. Kenaikan nilai THI di DKI Jakarta juga mengkonfirmasi penelitian Wati and Fatkhuroyan (2017) yang juga menemukan kenaikan THI di beberapa tempat di DKI Jakarta selama periode 19852012. Secara visual tampak grafik THI dan jumlah penduduk memiliki pola yang mirip, hal ini juga ditunjukkan dengan nilai korelasi simultan sebesar $+0,81$, korelasi lag-time 1 tahun sebesar $+0,69$ dan korelasi lag-time 2 tahun sebesar $+0,67$. Jumlah penduduk merepresentasikan jumlah aktivitas manusia atau aktivitas antropogenik di dalamnya yang memberikan dampak pada kenaikan suhu udara permukaan pada suatu daerah urban (Du et al., 2016; Zhang \& Sun, 2019). Berdasarkan hal tersebut, sangat dimungkinkan jika kedua variabel tersebut memiliki keterkaitan yang cukup baik. Korelasi simultan yang tinggi menunjukkan peningkatan jumlah penduduk dimana ada aktivitas antropogenik di dalamnya dapat berdampak langsung terhadap peningkatan suhu di Pulau Jawa.

\section{KESIMPULAN}

Sebagian besar suhu udara permukaan di utara Pulau Jawa lebih tinggi dengan $\mathrm{RH}$ yang lebih rendah daripada di selatan Pulau Jawa dengan perubahan suhu selama 4 dekade di seluruh Pulau jawa berkisar antara -0.27 hingga $1,17^{\circ} \mathrm{C}$ dan perubahan kelembaban sebesar $-2,21 \%$ hingga $0,77 \%$. Secara umum, terjadi perubahan yang didominasi oleh kenaikan dari indeks THI selama 4 dekade terutama pada bulan Juni di Pulau Jawa sebesar -0.15 hingga $0.72{ }^{\circ} \mathrm{C}$, kenaikan tertinggi diamati terjadi di sekitar DKI Jakarta. Perubahan positif THI yang cukup besar ini dapat merubah kategori Cold menjadi Comfortable, Comfortable menjadi Enough comfortable, dan Enough comfortable menjadi Discomfort.

Keterkaitan jumlah penduduk di DKI Jakarta dengan THI ditunjukkan dengan nilai korelasi simultan sebesar 0,81 , korelasi lag 1 tahun sebesar 0,69, sementara korelasi lag 2 tahun sebesar 0,67. Hal ini menunjukkan peningkatan jumlah penduduk berkontribusi pada peningkatan suhu yang berpengaruh pada kenyamanan manusia pada tahun yang sama.

\section{UCAPAN TERIMA KASIH}

Ucapan terima kasih penulis sampaikan kepada ECMWF yang telah menyediakan data dengan resolusi yang cukup baik sehingga tujuan penulisan karya tulis ilmiah ini dapat terlaksana. Terimakasih kepada BPS yang telah menyusun, menginventarisir dan menyediakan buku Jakarta dalam angka sehingga penulis dapat mendapatkan informasi jumlah penduduk di DKI Jakarta. Terimakasih kepada pihak yang berkontribusi pada Kerjasama BMKG-IPB yang telah memberikan kesempatan dan kepercayaan bagi penulis dalam menyelesaikan karya tulis ini. Penelitian ini didanai oleh BMKG sebagai prasyarat penyelesaian studi di IPB. 


\section{KONTRIBUSI PENULIS}

Penulis Pertama mengumpulkan data, melakukan desain metode, pengolahan data, membuat script untuk aplikasi GrADS, analisis data, pembahasan dan membuat naskah publikasi, Penulis Kedua mendesain interpretasi hasil dan review naskah publikasi, dan Penulis Ketiga mengumpulkan data, melakukan desain metode, menyusun abstraksi dan pembahasan.

\section{DAFTAR PUSTAKA}

Alfian, R., Nuraini, N., \& Uran, R. S. (2018). entifikasi Termal Humidity Index (THI) Lanskap Jalan Soekarno Hatta Kota Malang, Jawa Timur (Identification of Thermal Humidity Index (THI) of Soekarno Hatta Street Landscape, Malang City, East Java). Paper presented at the Seminar Nasional Kota Berkelanjutan.

Andani, N. D., \& Sasmito, B. (2018). Pengaruh Perubahan Tutupan Lahan Terhadap Fenomena Urban Heat Island dan Keterkaitannya dengan Tingkat Kenyamanan Termal (Temperature Humidity Index) di Kota Semarang. Jurnal Geodesi Undip, 7(3), 53-65.

Badan Pusat Statistik. (1997). Jakarta Dalam Angka 1997: Kantor Statistik Propinsi DKI Jakarta, Jakarta.

Badan Pusat Statistik. (1998). Jakarta Dalam Angka 1998: BPS Propinsi DKI Jakarta, Jakarta.

Badan Pusat Statistik. (1999). Jakarta Dalam Angka 1999: BPS Propinsi DKI Jakarta, Jakarta.

Badan Pusat Statistik. (2002). Jakarta Dalam Angka 2002: BPS Propinsi DKI Jakarta, Jakarta.

Badan Pusat Statistik. (2003). Jakarta Dalam Angka 2003: BPS Propinsi DKI Jakarta, Jakarta.

Badan Pusat Statistik. (2004). Jakarta Dalam Angka 2004: BPS Propinsi DKI Jakarta, Jakarta.

Badan Pusat Statistik. (2006). Jakarta Dalam Angka 2006: BPS Propinsi DKI Jakarta, Jakarta.

Badan Pusat Statistik. (2007). Jakarta Dalam Angka 2007: BPS Propinsi DKI Jakarta, Jakarta.

Badan Pusat Statistik. (2008). Jakarta Dalam Angka 2008: BPS Propinsi DKI Jakarta, Jakarta.

Badan Pusat Statistik. (2009). Jakarta Dalam Angka 2009: BPS Propinsi DKI Jakarta, Jakarta.

Badan Pusat Statistik. (2010). Jakarta Dalam Angka 2010: BPS Propinsi DKI Jakarta, Jakarta.

Badan Pusat Statistik. (2011). Jakarta Dalam Angka 2011: BPS Propinsi DKI Jakarta, Jakarta.

Badan Pusat Statistik. (2012). Jakarta Dalam Angka 2012: BPS Propinsi DKI Jakarta, Jakarta.

Badan Pusat Statistik. (2013). Jakarta Dalam Angka 2013: BPS Propinsi DKI Jakarta, Jakarta.

Badan Pusat Statistik. (2014). Jakarta Dalam Angka 2014: BPS Propinsi DKI Jakarta, Jakarta.

Badan Pusat Statistik. (2015). Jakarta Dalam Angka 2015: BPS Propinsi DKI Jakarta, Jakarta.

Badan Pusat Statistik. (2016). Jakarta Dalam Angka 2016: BPS Propinsi DKI Jakarta, Jakarta.

Badan Pusat Statistik. (2017). Jakarta Dalam Angka 2017: BPS Propinsi DKI Jakarta, Jakarta.

Badan Pusat Statistik. (2018). Jakarta Dalam Angka 2018: BPS Propinsi DKI Jakarta, Jakarta.

Badan Pusat Statistik. (2019). Jakarta Dalam Angka 2019: BPS Propinsi DKI Jakarta, Jakarta.

Badan Pusat Statistik. (2020a). Jakarta Dalam Angka 2020: BPS Propinsi DKI Jakarta, Jakarta.

Badan Pusat Statistik. (2020b). Kepadatan Penduduk menurut Provinsi (jiwa/km2), 2015-2019. Diakses tanggal 22 November 2020 dari https://www.bps.go.id/indicator/12/141/1/kepadatanpenduduk-menurut-provinsi.html

Berman, F., Chien, A., Cooper, K., Dongarra, J., Foster, I., Gannon, D., . . Mellor-Crumme, J. (2001). The GrADS project: Software support for high-level grid application development. The International Journal of High Performance Computing Applications, 15(4), 327-344. doi:10.1177/109434200101500401

Biro Pusat Statistik. (1982). Jakarta Dalam Angka 1982: Kantor Statistik Propinsi DKI Jakarta, Jakarta.

Biro Pusat Statistik. (1983). Jakarta Dalam Angka 1983: Kantor Statistik Propinsi DKI Jakarta, Jakarta.

Biro Pusat Statistik. (1985). Jakarta Dalam Angka 1985: Kantor Statistik Propinsi DKI Jakarta, Jakarta.

Biro Pusat Statistik. (1986). Jakarta Dalam Angka 1986: Kantor Statistik Propinsi DKI Jakarta, Jakarta.

Biro Pusat Statistik. (1987). Jakarta Dalam Angka 1987: Kantor Statistik Propinsi DKI Jakarta, Jakarta.

Biro Pusat Statistik. (1988). Jakarta Dalam Angka 1988: Kantor Statistik Propinsi DKI Jakarta, Jakarta.

Biro Pusat Statistik. (1991). Jakarta Dalam Angka 1991: Kantor Statistik Propinsi DKI Jakarta, Jakarta.

Biro Pusat Statistik. (1992). Jakarta Dalam Angka 1992: Kantor Statistik Propinsi DKI Jakarta, Jakarta.

Biro Pusat Statistik. (1993). Jakarta Dalam Angka 1993: Kantor Statistik Propinsi DKI Jakarta, Jakarta.

Biro Pusat Statistik. (1995). Jakarta Dalam Angka 1995: Kantor Statistik Propinsi DKI Jakarta, Jakarta.

Biro Pusat Statistik. (1996). Jakarta Dalam Angka 1996: Kantor Statistik Propinsi DKI Jakarta, Jakarta.

Du, H., Wang, D., Wang, Y., Zhao, X., Qin, F., Jiang, H., \& Cai, Y. (2016). Influences of land cover types, meteorological conditions, anthropogenic heat and urban area on surface urban heat island in the Yangtze River Delta Urban Agglomeration. Science of the total environment, 571, 461-470. doi:10.1016/ j.scitotenv.2016.07.012

Enander, A. E. (1989). Effects of thermal stress on human performance. Scandinavian journal of work, environment \& health, 15 (1), 27-33.

Harahap, F. R. (2013). Dampak urbanisasi bagi perkembangan kota di Indonesia. Society, 1(1), 35-45. doi:10.33019/society.v1i1.40

Hartmann, D. L. (2015). Global physical climatology (Vol. 103): Newnes.

Hennermann, K., \& Berrisford, P. (2017). ERA5 data documentation. Copernicus knowledge base. Diakses tanggal 2 Desember 2020 dari https://confluence.ecmwf.int/display/CKB/ERA5\% $3 \mathrm{~A}+$ data+documentation

Hersbach, H., Bell, B., Berrisford, P., Hirahara, S., Horányi, A., Muñoz冈Sabater, J., . . . Schepers, D. (2020). The ERA5 global reanalysis. Quarterly Journal of the Royal Meteorological Society, 146(730), 1999-2049. doi:10.1002/qj.3803

Ige, S. O., Ajayi, V. O., Adeyeri, O., \& Oyekan, K. (2017). Assessing remotely sensed temperature humidity index as human comfort indicator relative to landuse landcover change in Abuja, Nigeria. Spatial Information Research, 25(4), 523-533. doi:10.1007/ s41324-017-0118-2

Johannessen, O. M., Bengtsson, L., Miles, M. W., Kuzmina, S. I., Semenov, V. A., Alekseev, G. V., . . . Pettersson, L. H. (2004). Arctic climate change: observed and modelled temperature and sea-ice variability. Tellus A: Dynamic Meteorology and Oceanography, 56(4), 328-341. doi:10.3402/tellusa.v56i4.14418

Kusminingrum, N., \& Gunawan, G. (2008). Polusi udara akibat aktivitas kendaraan bermotor di jalan perkotaan Pulau Jawa dan Bali. Laporan penelitian, Puslitbang Jalan dan Jembatan., Kementerian Pekerjaan Umum: Bandung.

Lawrence, M. G. (2005). The relationship between relative humidity and the dewpoint temperature in moist air: A simple conversion and applications. Bulletin of the American Meteorological Society, 86(2), 225-234. doi:10.1175/BAMS-86-2-225

Marsitha, F., Pattipeilohy, W. J., \& Virgianto, R. H. (2019). Kenyamanan Termal Klimatologis Kota-Kota Besar Di Pulau Sulawesi Berdasarkan Temperature Humidity Index (Thi). Jurnal Saintika Unpam: Jurnal Sains dan Matematika Unpam, 1(2), 202-211. doi:10.32493/jsmu.v1i2.2384 
McGregor, G. R., \& Nieuwolt, S. (1998). Tropical climatology: an introduction to the climates of the low latitudes: John Wiley \& Sons Ltd.

Murphy, B. F., \& Timbal, B. (2008). A review of recent climate variability and climate change in southeastern Australia. International Journal of Climatology: A Journal of the Royal Meteorological Society, 28(7), 859-879. doi:10.1002/joc.1627

Njoku, C. A., \& Daramola, M. T. (2019). Human outdoor thermal comfort assessment in a tropical region: a case study. Earth Systems and Environment, 3(1), 29-42. doi:10.1007/s41748-01900090-4

Nogueira, M. (2020). Inter-comparison of ERA-5, ERA-interim and GPCP rainfall over the last 40 years: Process-based analysis of systematic and random differences. Journal of Hydrology, 583, 124632.

Ramadhan, F., \& Osly, P. J. (2019). Analisis Ketersediaan Ruang Terbuka Hijau Dan Kecukupannya Di Kota Depok. Jurnal Infrastruktur, 5(1), 7-11. doi:10.35814/infrastruktur.v5i1.663

Rilo, P., Budi, S. T., \& Ananto, A. (2018). Kajian Sebaran Penutup Lahan dan Nilai Temperature Humidity Index (THI) Kampus Universitas Negeri Semarang (UNNES). Geo-Image, 7(2), 111122. doi:10.15294/geoimage.v7i2.23453

Setiawan, B., \& Ma'mun, M. (2021). Climate trends and rainfall patterns in the Ciliwung watershed, West Java of Indonesia. Paper presented at the IOP Conference Series: Earth and Environmental Science.

Smolander, J. (2002). Effect of cold exposure on older humans. International journal of sports medicine, 23(02), 86-92. doi:10.1055/s-2002-20137

Supari, Tangang, F., Juneng, L., \& Aldrian, E. (2017). Observed changes in extreme temperature and precipitation over Indonesia. International Journal of Climatology, 37(4), 1979-1997. doi:10.1002/joc.4829

Susanti, I., Rizki, N. A. I., \& Maryadi, E. (2019). Pemantauan Suhu Permukaan Tanah Di Pulau Jawa. Berita Dirgantara, LAPAN, 20(2).

Tseliou, A., Tsiros, I. X., Lykoudis, S., \& Nikolopoulou, M. (2010). An evaluation of three biometeorological indices for human thermal comfort in urban outdoor areas under real climatic conditions. Building and Environment, 45(5), 1346-1352. doi:10.1016/j.buildenv.2009.11.009

Tursilowati, L., \& Djundjunan, J. D. (2007). Use of remote sensing and GIS to compute temperature humidity index as human comfort indicator relate with land use-land cover change (LULC) in Surabaya. Paper presented at the The 73rd International Symposium on Sustainable Humanosphere.

Wati, T., \& Fatkhuroyan, F. (2017). Analisis Tingkat Kenyamanan Di DKI Jakarta Berdasarkan Indeks THI (Temperature Humidity Index). Jurnal Ilmu Lingkungan, 15(1), 57-63.

Wilson, T. E., \& Crandall, C. G. (2011). Effect of thermal stress on cardiac function. Exercise and sport sciences reviews, 39(1), 12. doi:10.1097/JES.0b013e318201eed6

Wuebbles, D. J., Brasseur, G. P., Rodhe, H., Barrie, L. A., Crutzen, P. J., Delmas, R. J., ... Steffen, W. (2003). Changes in the chemical composition of the atmosphere and potential impacts. In Atmospheric Chemistry in a Changing World (pp. 1-17): Springer.

Zhang, Y., \& Sun, L. (2019). Spatial-temporal impacts of urban land use land cover on land surface temperature: Case studies of two Canadian urban areas. International Journal of Applied Earth Observation and Geoinformation, 75, 171-181. doi:10.1016/ j.jag.2018.10.005 